\title{
Characteristics of carcass and non-carcass components in feedlot native goats in the Brazilian semiarid region ${ }^{1}$
}

\section{Andrea Souza da Silva ${ }^{2}$, Dermeval Araújo Furtado ${ }^{3}$, Ariosvaldo Nunes de Medeiros ${ }^{3}$, Roberto Germano Costa ${ }^{3}$, Marcílio Fontes Cezar ${ }^{4}$, José Morais Pereira Filho ${ }^{4}$}

\author{
1 Projeto financiado pelo CNPq. \\ 2 Programa de Pós-graduação em Zootecnia/UFPB - Areia-PB, Brazil, 58397-000. \\ ${ }^{3}$ Departamento de Zootecnia/CCA/UFPB, Campus de Areia - PB, Brazil, 58397-000. \\ ${ }^{4}$ Departamento de Zootecnia/CSTR/UFCG, Campus de Patos - PB, Brazil , 58700-970.
}

\begin{abstract}
The objective of this study was to evaluate the characteristics of carcass and non-carcass components in Brazilian semi-arid native goats of different genotypes in feedlot system. It was used 30 non-castrated Azul, Graúna and Moxotó goats with average initial weight of $15.93 \pm 2.4$, distributed in a completely randomized design with 3 genotypes and 10 replicates. The experimental diet used had a roughage:concentrate ratio of 47:53. There was a significant effect for weight gain and subcutaneous fat thickness according to genotype. Retail cut yields did not differ among the studied breeds. The percentage of non-carcass components in relation to live weight and empty body weight were not different among genotypes. Graúna and Azul genotypes showed daily gain greater than Moxotó genotype. The subcutaneous fat thickness presented by Azul and Moxotó genotypes was greater than that of Graúna genotype. All genotypes have good quantitative and morphometric carcass traits in addition to satisfactory yields of cut and non-carcass components, but for subcutaneous fat thickness (carcass finishing), Azul and Moxotó genotypes stand out.
\end{abstract}

Key Words: carcass dressing, native breeds, performance, retail cuts, slaughter weight

\section{Introduction}

Goat breeding is an activity of great importance in Northeastern Brazil, playing an important role in the context of local agribusiness, being an alternative income source based on the marketing of meat, milk and skin. However, the level of production achieved by farmers in this region is still low, making it difficult to work with the market segments and the supply chain. Goat breeding for meat production has emerged as an increasing activity in Brazil, which can be confirmed by the growing demand for goat meat, followed by the introduction of specialized breeds for meat production in the country. However, according to Araújo et al. (2008), in Brazil, especially in the Northeastern region, which has the largest herd of goats, often allied to family farming in the semiarid region, the main effective population consists of small animals adapted to the ecological conditions of the region.

In northeastern Brazil, goat herds are composed of native breeds and animals of undefined breed (SPRD) of remarkable rusticity, but with low milk and meat production and with little genetic variability (Ribeiro et al., 2004). The study of different genotypes under intensive system contributes considerably for the productive outcome of this type of system inasmuch as they are directly related to the weight:gain ratio, precocity:feeding conversion ratio, which are related to food costs and carcass quality.

The objective of studying carcass is to evaluate subjective and objective parameters related to qualitative and quantitative aspects (Garcia et al., 2003). Thus, the value of a carcass depends, among other factors, on the body weight:slaughter age ratio, whose objective is to obtain higher weights at younger ages in order to meet the demands of the consumer market (Mattos et al., 2006).

The use of appropriate and varied retail cuts can also enhance the differentiation of prices and rational use of products, enabling higher profitability to the producer (Costa et al., 2010).

The non-carcass components traditionally served only to cover parts of the costs generated during slaughter. Currently, their higher commercial value has encouraged producers to adopt better sanitary cares for further use of the viscera and to improve the management conditions so that the genotype can show all its genetic potential, providing an alternative source of healthy food for the population and profitable for its revenue.

The objective of this study was to evaluate the characteristics of carcass and non-carcass components in feedlot native goats from different genotypes. 


\section{Material and Methods}

The experiment was conducted at the Estação Experimental de Pesquisa em Pequenos Ruminantes - UFPB, located at the municipality of São João do Cariri ( $7^{\circ} 23^{\prime} 27^{\prime \prime}$ S and $36^{\circ} 31^{\prime}$ 58" W), micro-region of Eastern Cariri, state of Paraíba, in the Brazilian semi-arid region. The local climate is classified as Bsh (hot semi-arid) according to Köppen classification, with average annual temperatures of $26^{\circ} \mathrm{C}$, annual rainfall of $395 \mathrm{~mm}$ with irregular distribution, and the dry season lasting over eight months and relative air humidity of approximately $68 \%$.

A total of 30 non-castrated Azul, Graúna and Moxotó goats with average initial weight of $15.93 \pm 2.4$ were used. The animals were confined in three open barns, covered with ceramic tiles, east-west oriented, consisting of 10 individual stalls in each barn, area of $3.75 \mathrm{~m}^{2}$ per stall, provided with feed box and drinking trough. The experiment lasted 121 days; the first 21 days were for adaptation of animals to experimental conditions and 100 days were used for data collection.

The experimental diet (Tables 1 and 2 ), with $47 \%$ forage and $53 \%$ concentrate, was composed of cactus pear, Buffel hay, corn grain, soybean meal and mineral supplement, which was formulated according to NRC recommendations (1981) to meet the nutritional requirements of animals with $15 \mathrm{~kg}$ of live weight and to provide average daily weight gains of $150 \mathrm{~g}$, being offered twice daily (8 a.m. and 4 p.m.) in the form of complete mixture.

Weekly weightings were performed to monitor body development, until the animals reached final live weight (FLW) of $20 \mathrm{~kg}$, set for slaughter. The animals were fasted for $16 \mathrm{~h}$ for determination of the live weight at slaughter (LWS). Then, the animals were stunned by brain concussion followed by bleeding through section of carotid arteries and jugular vein, with subsequent blood collection. After skinning and evisceration, the digestive tract (DT) was weighed and emptied to obtain the empty body weight
(EBW = LWS - digestive tract content), and the true or biological yield, according to methodology described by Silva Sobrinho (2001). Viscera, skin, head, as well as metatarsal and metacarpal limbs were quantified. The weight of non-carcass components was obtained from the sum of edible components (blood, lung + trachea, spleen, heart, liver, kidneys, empty gastrointestinal tract, omental and perirenal fat, head and feet) and its percentage in relation to live weight at slaughter was obtained according to methodology described by Costa (1990) using the following formula: Buchada Yield BY $(\%)=[(\Sigma O C(\mathrm{~kg}) / \mathrm{LWS}(\mathrm{kg}))] \times 100$, also determined in relation to the empty body weight, in which the weight of the gastrointestinal contents, bladder and gallbladder were not considered, using the following formula: Buchada Yield = $[(\Sigma \mathrm{OC}(\mathrm{kg}) / \mathrm{EBW}(\mathrm{kg}))] \times 100$. After evisceration, carcasses were weighed to obtain hot carcass weight $(\mathrm{HCW})$, hot carcass yield $(\mathrm{HCY}=\mathrm{HCW} / \mathrm{LWS} \times 100)$ and biological or true carcass yield $(\mathrm{TCY}=\mathrm{HCW} / \mathrm{EBW} \times 100)$. Then, the carcasses were transported to cold storage at $4^{\circ} \mathrm{C}$ for 24 hours; hang by the calcaneal tendons by using hooks suitable for the maintenance of tarsal metatarsal joints spaced approximately by $17 \mathrm{~cm}$. After this period, carcasses were weighed to obtain the cold carcass weight (CCW), also by calculating the weight loss due to cooling (WLC = $\mathrm{HCW}-\mathrm{CCW}) / \mathrm{HCW} \times 100$ and cold carcass yield $(\mathrm{CCY}=$ $\mathrm{CCW} / \mathrm{LWS}) \times 100$.

After cooling, the following measurements were made in the carcass using methodology adapted from Cezar \& Sousa (2007): carcass external length; carcass internal length, hip width, hip circumference, chest width and depth, leg length, leg circumference, also determining the carcass compactness index (cold carcass weight divided by the carcass internal length) and leg compactness (leg weight divided by leg length).

The carcasses were divided into right and left carcass, after performing cuts in 5 anatomical regions (shoulder, leg, neck, loin and ribs) according to methodologies described by Cezar \& Sousa (2007).

Table 1 - Chemical composition of ingredients of the experimental diet in dry matter basis

\begin{tabular}{|c|c|c|c|c|c|}
\hline & \multicolumn{5}{|c|}{ Ingredient } \\
\hline & Buffel hay & Cactus pear & Mineral supplement & Soybean meal & Corn meal \\
\hline Dry matter (\%) & 86.46 & 9.80 & 97.10 & 90.00 & 87.09 \\
\hline Organic matter (\% MS) & 87.67 & 89.12 & - & 93.11 & 98.42 \\
\hline Mineral matter (\% MS) & 12.33 & 10.88 & 86.08 & 6.89 & 1.58 \\
\hline Crude protein (\% MS) & 5.10 & 3.10 & - & 48.50 & 9.20 \\
\hline Neutral detergent fiber (\% MS) & 72.40 & 28.90 & - & 14.08 & 12.45 \\
\hline Acid detergent fiber (\% MS) & 48.30 & 20.40 & - & 10.40 & 5.90 \\
\hline Ether extract (\% MS) & 1.20 & 1.25 & - & 1.41 & 4.06 \\
\hline Total carbohydrates (\% MS) & 81.37 & 84.77 & - & 43.20 & 85.16 \\
\hline Non-fiber carbohydrates (\% MS) & 8.97 & 55.87 & - & 29.12 & 72.71 \\
\hline
\end{tabular}


Table 2 - Ingredients and chemical composition of the experimental diet in dry matter basis

\begin{tabular}{lc}
\hline Ingredient & $(\%)$ \\
\hline Buffel hay & 35.00 \\
Cactus pear & 12.00 \\
Mineral supplement & 1.00 \\
Soybean meal & 13.00 \\
Corn meal & 39.00 \\
Bromatological composition (\%) & \\
Dry matter & 44.80 \\
Organic matter & 92.01 \\
Mineral matter & 7.99 \\
Crude Protein & 12.05 \\
Metabolizable energy (Mcal) ${ }^{2}$ & 2.32 \\
Ether extract & 1.77 \\
Total carbohydrate & 78.19 \\
Non-fibrous carbohydrates & 42.69 \\
Neutral detergent fiber & 35.50 \\
Acid detergent fiber & 23.02 \\
\hline 1 Mineral supplement (nutrient/kg supplement): vitamin A - 135,000.00 IU; \\
$\quad$ vitamin D3 - 68,000.00. IU; vitamin E - 450.00 IU; calcium - 240 g; phosphorus - 71 g; \\
potassium - 28.2 g; sulfur - 20 g; magnesium - 20 g; copper - 400 mg; cobalt - 30 mg; \\
chromium - 10 mg; iron - 2,500 mg; iodine - 40 mg; manganese - 1,350 mg; \\
selenium - 15 mg; zinc - 1,700 mg; maximum fluoride - 710 mg; solubility of \\
phosphorus (P) in citric acid - 2\% (min.).
\end{tabular}

The experiment used a complete randomized design (CRD) with 3 genotypes and 10 replications and the means of genotypes were compared by the Tukey test at 5\% probability by the SAEG statistical program version 9.1 (2007), using the following statistical model:

$$
\mathrm{Yij}=\mathrm{m}+\mathrm{Gi}+\mathrm{eij}
$$

in which Yij = observed value for each characteristic of animal $\mathrm{j}$, of genotype $\mathrm{I} ; \mathrm{m}$ = overall mean of population; $\mathrm{Gi}$ = genotype effect; eij = random error associated with each observation.

\section{Results and Discussion}

The results of the carcass dressing for the different genetic groups (Table 3 ), showed no effect $(\mathrm{P}>0.05)$ for the variables related to weights and hot, cold and biologic carcass yields, except for the daily weight gain and subcutaneous fat thickness, which differed $(\mathrm{P}<0.05)$ among genotypes. The results of weight gain showed that Graúna genotype showed daily gain (35 g/day) higher than Moxotó genotype (19 g/day), but similar to Azul genotype (34 g/day). The goats did not obtain the weight gain proposed with the formulation of the experimental diet based on NRC (1981). The reduced weight gain may be associated with the low dry matter intake ( $2.7 \%$ of $\mathrm{LW}$ ) inasmuch as the estimated gain was (3.0\% LW).

Moxotó and Azul genotypes showed similar fat thicknesses values, 0.62 and $0.44 \mathrm{~mm}$, respectively, but different from that of Graúna genotype, which was $0.22 \mathrm{~mm}$.

Although the means are significantly different, the fat thicknesses found are low. According to Cezar \& Sousa (2006), one of the most striking differences among species of small ruminants is that the subcutaneous adipose tissue in goats is poorly developed or scarce and almost all deposited in body cavities.

By studying the carcass traits of native Moxotó and Canindé goats submitted to two feeding levels (ad libitum and restricted), Mattos et al. (2006) also found no significant difference $(\mathrm{P}>0.05)$ for the variables related to weights and carcass yields. Cunha et al. (2000) assessed the carcass performance and characteristics of feedlot Saanen and Boer crossbred goats and found no significant effect among genotypes for weight at slaughter $(22.7 \mathrm{~kg})$, hot carcass yield (48.2\%) and retail commercial (46.05). McClelland et al. (1976) reported that most differences in body composition among different genotypes at the same weight reflect differences in relative maturity among breeds, which explains the findings of this study, inasmuch as according to ABCC (2000), native groups have similar size and weight at maturity.

Hot (46.17\%) and cold (43.59\%) carcass dressing in this experiment (Table 3 ) are in agreement with the carcass yield reported by Zapatta et al. (2001), who studied hot carcass yields in northeastern Brazil and found values ranging from

Table 3 - Means and coefficients of variation (CV) of weight and carcass dressing of feedlot native goats from different genotypes

\begin{tabular}{|c|c|c|c|c|c|}
\hline \multirow[t]{2}{*}{ Variable } & \multicolumn{3}{|c|}{ Genotype } & \multirow[b]{2}{*}{ Mean } & \multirow[t]{2}{*}{ CV (\%) } \\
\hline & Azul & Graúna & Moxotó & & \\
\hline Live weight at slaughter (kg) & 17.73 & 18.43 & 17.18 & 17.77 & 11.72 \\
\hline Hot carcass weight $(\mathrm{kg})$ & 8.09 & 8.78 & 7.83 & 8.23 & 15.93 \\
\hline Hot carcass yield (\%) & 45.55 & 47.45 & 45.53 & 46.17 & 8.85 \\
\hline Cold carcass weight $(\mathrm{kg})$ & 7.90 & 8.51 & 7.64 & 8.02 & 16.04 \\
\hline Biological yield (\%) & 55.02 & 56.12 & 54.34 & 55.16 & 7.80 \\
\hline Subcutaneous fat thickness $(\mathrm{cm})$ & 0.62 a & $0.22 \mathrm{~b}$ & $0.44 \mathrm{ab}$ & 0.43 & 67.47 \\
\hline
\end{tabular}

Means followed by different lowercase letters within the same row differ $(\mathrm{P}<0.05)$ by Tukey test. 
35.5 to $50 \%$ and for cold carcass yield, values from 35.5 to $41.1 \%$, taking into account different breeds, ages and slaughter weight. The values found were higher than those shown by Costa et al. (1990), who assessed carcass traits of native goats raised under traditional management in northeastern Brazil and found hot and cold carcass around 34.5 and 39.4, respectively. This superiority probably occurred due to the nutritional value of the diet used in the study, which showed roughage $\times$ concentrated ratio $(47 \%$ vs. 53\%), respectively, and to the farming system adopted, which according to Gonzaga Neto et al. (2006), are factors that directly influence carcass dressing.

The similarity of the live weight at slaughter, associated with the same age, probably contributed for the carcass yield not to be influenced by genotype because according to César \& Sousa (2007), among the intrinsic factors, probably the live weight at slaughter and age are those that influence carcass dressing most.

No significant effect of genotypes $(\mathrm{P}>0.05)$ was observed for any of the variables analyzed in the carcass morphometry (Table 4). By observing the same variables in feedlot Moxotó and Canindé goats submitted to two energy levels (2.2 and 2.7 Mcal), Lisboa et al. (2010), found no difference $(\mathrm{P}>0.05)$ between genotypes.

The mean values found for leg length, chest, thigh and hip circumference were 36.88, 57.16, 27.30 and $43.18 \mathrm{~cm}$, respectively, and rip width $(11.49 \mathrm{~cm})$ and chest depth (24.81) did not differ $(\mathrm{P}>0.05)$ between genotypes, which was probably caused by the morphological similarity among animals. However, the values were similar to those found by Lisboa et al. (2010), who found no significant difference ( $>0.05)$, whereas when studying carcass traits of feedlot Moxotó and Canindé goats submitted to two energy levels, found the following values of $32.69 \mathrm{~cm} ; 61.28,27.95$ and $42.83 \mathrm{~cm} ; 13.80 \mathrm{~cm}$ and 25.01 for leg length, chest, thigh and hip circumference, rip width and chest depth, respectively.

According to Cezar and Sousa (2007), the carcass and leg compactness index generate values that might allow a better evaluation of the carcass tissue composition, in relation to measures taken alone. Taking into account that genotypes in this study are native and have no specialized skills for meat production, the carcass compactness index in this work (Table $4 ; 0.17 \mathrm{~kg} / \mathrm{cm}$ ) was similar to that found by Santos Filho (1997), who studied the effect of live weight at slaughter on carcass traits of undefined breed goats and found an index of $0.14 / \mathrm{cm}$. However, Sousa et al. (2009) studied the carcass traits of $1 / 2$ Boer $\times 1 / 2$ Undefined Breed; Anglo-Nubian 1/2 × 1/2 Undefined Breed goats and feedlot Santa Ines lambs and found higher values $(0.22$, 0.19 and $0.22 \mathrm{~kg} / \mathrm{cm}$ respectively). The leg compactness index $(0.37 \mathrm{~kg} / \mathrm{cm})$ in this study was higher than that found by Grande et al. (2009), who evaluated quantitative carcass traits of feedlot $3 / 4$ Boer $+1 / 4$ Saanen goats submitted to different diets and found a mean value of $0.20 \mathrm{~kg} / \mathrm{cm}$ for this variable.

The similarity between genotypes is probably due to the fact that animals were slaughtered at the same weight range, living in the same facilities and fed the same diet combined with the genetic factor inasmuch as the genotypes studied show similar size and weight at maturity.

No significant effect $(\mathrm{P}>0.05)$ was observed in weight and percentage of retail cuts for feedlot native goats from different genotypes (Table 5), what can be explained by structural and morphological similarities among genotypes and the fact that they were all submitted to the same nutritional level. These results were similar to those found by Mattos et al. (2006), who studied feedlot Moxotó and Canindé goats fed ad libitum and with 30\% restriction, slaughtered at the same age to those of this research and observed no significant differences in the yield of retail cuts such as shoulder, leg, neck, loin and ribs, 20.33, 29.52, 12.73, 9.71 and $10.97 \%$ respectively. These values are close to those found in this study for the same variables: 21.12, $29.24,11.77,9.29$ and $25.45 \%$ respectively.

Average yields of leg (29.24\%), rib (25.45\%) and shoulder (21.12\%) found in this study are similar to those obtained

Table 4 - Means and coefficients of variation (CV) of the carcass morphometry of feedlot native goats from different genotypes

\begin{tabular}{|c|c|c|c|c|c|}
\hline \multirow[t]{2}{*}{ Variable } & \multicolumn{3}{|c|}{ Genotype } & \multirow[b]{2}{*}{ Mean } & \multirow[t]{2}{*}{ CV (\%) } \\
\hline & Azul & Graúna & Moxotó & & \\
\hline External length (cm) & 47.99 & 47.63 & 49.39 & 48.35 & 3.62 \\
\hline Carcass internal length (cm) & 46.70 & 47.50 & 46.60 & 46.93 & 3.10 \\
\hline Leg length (cm) & 36.81 & 37.10 & 36.75 & 36.88 & 6.48 \\
\hline Carcass compactness index $(\mathrm{kg} / \mathrm{cm})$ & 0.17 & 0.18 & 0.17 & 0.17 & 8.50 \\
\hline Leg compactness index $(\mathrm{kg} / \mathrm{cm})$ & 0.03 & 0.03 & 0.03 & 0.03 & 11.91 \\
\hline Chest circumference $(\mathrm{cm})$ & 57.45 & 57.55 & 56.50 & 57.16 & 3.16 \\
\hline Thigh circumference (cm) & 27.15 & 27.70 & 27.05 & 27.30 & 8.96 \\
\hline Rip circumference (cm) & 43.00 & 43.90 & 42.65 & 43.18 & 3.83 \\
\hline Rip width (cm) & 11.32 & 12.07 & 11.09 & 11.49 & 5.66 \\
\hline Chest depth (cm) & 24.95 & 24.90 & 24.60 & 24.81 & 3.48 \\
\hline
\end{tabular}


by Carvalho Junior et al. (2009), when analyzing the effect of supplementation on the carcass traits of F1 Boer $x$ Undefined Breed goats finished on native pasture (30, 24.31 and 21.79\%, respectively). However, Hashimoto et al. (2007), studied the carcass traits of feedlot Boer $\times$ Saanen goats fed diets with soybean hulls replacing corn and found average yield of rib (21.55\%) and loin (7.96\%) lower than those found in the present work. These results are satisfactory because they were native animals with no specialized skills for meat production, which showed significant participation in cuts of higher commercial value.

According to Yanez (2006), the participation of cuts in the carcass allows a qualitative assessment because it should present the best possible proportion of cuts with higher content of edible tissues, mainly muscles, or the best proportion of cuts of interest to consumers. Considering the similarity between breeds, the results obtained as for the cut percentages reinforce the Law of Anatomical Harmony (Boccard \& Dumont, 1960), in which carcasses with similar weights and fat content tend to present similar regional composition regardless of the conformation observed. The sum of percentages of cuts of higher commercial value (shoulder, leg and loin) in relation to the weight of the cold half carcass of this study was around 59.65\%.
There was no significant effect $(\mathrm{P}>0.05)$ for noncarcass components (Table 6). These results were similar to those of Mattos et al. (2006), who found no significant effect $(\mathrm{P}>0.05)$ for non-carcass components of goats in function of their genotypes. Again, this result can be attributed to morphological and genetic similarities among breeds and to the environment which these animals were submitted to during the experiment, which contributed to the uniformity of data and similar slaughter weight.

The mean yield of non-carcass components in relation to the live weight at slaughter found in the present study was $17.05 \%$. According to Costa et al. (2003), the mean yield of non-carcass components represents approximately $18 \%$ of the total yield in relation to the live weight at slaughter, corroborating this study.

It is worth mentioning the significance of the yield of non-carcass components in relation to the empty body weight, which was $20.35 \%$. This result shows that when the yields were compared to live weight and empty body weight, the latter showed a greater absolute value inasmuch as it does not consider gastrointestinal contents, which according to some authors, may vary from 10 to $20 \%$ of the live weight according to the feeding system.

Table 5 - Means and coefficients of variation (CV) of weights and percentage of retail cuts of feedlot native goats from different genotypes

\begin{tabular}{|c|c|c|c|c|c|}
\hline \multirow[t]{2}{*}{ Variable } & \multicolumn{3}{|c|}{ Genotype } & \multirow[b]{2}{*}{ Mean } & \multirow[b]{2}{*}{ CV (\%) } \\
\hline & Azul & Graúna & Moxotó & & \\
\hline Shoulder & 0.85 & 0.90 & 0.83 & 0.86 & 14.27 \\
\hline Leg & 1.18 & 1.26 & 1.14 & 1.19 & 13.29 \\
\hline Neck & 0.92 & 1.00 & 0.86 & 0.93 & 21.67 \\
\hline Loin & 0.37 & 0.41 & 0.36 & 0.38 & 20.85 \\
\hline Rib & 0.99 & 1.09 & 1.03 & 1.04 & 17.63 \\
\hline \multicolumn{6}{|c|}{ Yield percentage (\%) } \\
\hline Shoulder & 21.12 & 21.14 & 21.11 & 21.12 & 4.63 \\
\hline Leg & 29.04 & 29.61 & 29.06 & 29.24 & 5.78 \\
\hline Neck & 12.11 & 11.21 & 11.99 & 11.77 & 18.72 \\
\hline Loin & 9.13 & 9.54 & 9.18 & 9.29 & 11.01 \\
\hline Rib & 24.61 & 25.59 & 26.13 & 25.45 & 11.42 \\
\hline
\end{tabular}

Table 6 - Mean and coefficients of variation (CV) of non-carcass components of feedlot native goats from different genotypes

\begin{tabular}{|c|c|c|c|c|c|}
\hline \multirow[t]{2}{*}{ Variable } & \multicolumn{3}{|c|}{ Genotype } & \multirow[b]{2}{*}{ Mean } & \multirow[b]{2}{*}{ CV $(\%)$} \\
\hline & Azul & Graúna & Moxotó & & \\
\hline Viscera from non-carcass components ${ }^{1}$ (kg) & 3.03 & 3.39 & 3.24 & 3.22 & 16.47 \\
\hline Yield of non-carcass components: LWS ${ }^{2}(\%)$ & 16.13 & 18.25 & 16.78 & 17.05 & 15.45 \\
\hline Yield of non-carcass components: EBW EB) $^{3}(\%)$ & 19.52 & 21.52 & 20.02 & 20.35 & 13.95 \\
\hline Head + feet $(\mathrm{kg})$ & 1.90 & 1.97 & 1.84 & 1.90 & 7.50 \\
\hline Head + feet:LWS (\%) & 10.83 & 10.74 & 10.80 & 10.79 & 8.85 \\
\hline Head + feet:EBW (\%) & 13.10 & 12.73 & 12.91 & 12.92 & 9.95 \\
\hline
\end{tabular}

${ }^{1}$ Sum of weights of blood, lung, trachea, spleen, heart, liver, kidneys, empty gastrointestinal tract, omental and perirenal fat, head and feet.

${ }^{2}$ Yield of non-carcass components in relation to the live weight at slaughter.

${ }^{3}$ Yield of non-carcass components in relation to the empty body weight. 
In this study, head and feet are sold together with the viscera used to make the typical dish buchada or noncarcass components, which are submitted to a rigorous cleaning process, removing around $50 \%$ of non-edible components such as skin of the head and feet, ears, eyes, muzzle and upper and lower jaw, as well as cooking losses. By adding to the mean weight of viscera used in the buchada (3.22 kg), head and feet (1.90 kg), and considering a loss due to the cleaning process of $50 \%$ of the mean weight $(0.95 \mathrm{~kg})$, about $4.16 \mathrm{~kg}$ available for sale would be obtained. This weight would represent approximately 23.46 and $27.62 \%$ in relation to the mean slaughter and empty body weights.

According to Osorio et al. (2002), the quality of the animal yield does not depend only on the carcass yield and its cuts, but also on the proportion and quality of the other components, requiring the appreciation of these components so that the commercialization would be fair for producers who seek total quality, benefiting also consumers, both for the lower price as for the improved health aspect.

\section{Conclusions}

If the quantitative characteristics and morphometry of the carcass, cut yields and non-carcass components are considered, any of the genotypes can be exploited; however, in terms of subcutaneous fat thickness (carcass finishing), Azul and Moxotó genotypes are the most indicated.

\section{References}

AEL KHIDIR, I.A.; BABIKER, S.A.; SHAFIE, S.A. Comparative feedlot performance and carcass characteristics of sudanese desert sheep. Small Ruminant Research, n.30, p.147-151, 1998.

ARAÚJO, A.M.; PIRES, L.C.; SILVA, F.L.R. et al. Distância Genética em Caprinos Naturalizados por meio de Microssatélites de DNA. In: SIMPÒSIO BRASILEIRO DE MELHORAMENTO ANIMAL, 7., 2008, São Carlos. Anais... São Carlos: Sociedade Brasileira de Melhoramento Animal/SBMA, 2008. p.1-4.

ASSOCIAÇÃO BRASILEIRA DE CRIADORES DE CAPRINOS ABCC. Regulamento do serviço de registro genealógico das raças caprinas. Recife: ABCC, 2000. 16p.

BUENO, M.S.; SANTOS, L.E.; CUNHA, E.A. et al. Avaliação de carcaças de cabritos com diferentes pesos vivos. Boletim de Industria Animal, v.2, n.54, p.61-67, 1997.

BOCCARD, R.; DUMONT, B.L. Etude de la production de la viande chez les ovins. II variation de l'importance relativedes differents régions corporelles de l'agneau de boucherie. Annales de Zootechnie, v.9, n.4, p.355-365, 1960.

CARVALHO JÚNIOR, A.M.; FILHO PEREIRA, J.M.; SILVA, R.M. et al. Efeito da suplementação nas características de carcaça e dos componentes não-carcaça de caprinos F1 Boer x SRD terminados em pastagem nativa. Revista Brasileira de Zootecnia, v.38, n.7, p.1301-1308, 2009.

CEZAR, M.F.; SOUSA, W.H. Avaliação e utilização da condição corporal como ferramenta de melhoria da reprodução e produção de ovinos e caprinos de corte. In: REUNIÃO ANUAL DA SOCIEDADE BRASILEIRA DE ZOOTECNIA, 43., 2006, João Pessoa. Anais... João Pessoa: Sociedade Brasileira de Zootecnia, 2006. (CD-ROM).

CEZAR, M.F.; SOUSA, W.H. Carcaças ovinas e caprinas: obtenção-avaliação-classificação. Uberaba: Agropecuária Tropical, 2007. 232p.

COSTA, R.G.; PIMENTA FILHO, E.C.; MOREIRA, R.T. et al. Rendimento de carcaça e vísceras em caprinos mestiços AngloNubianos. Agropecuária Técnica, v.11, n.1/2, p.3-8, 1990.

COSTA, R.G.; MEDEIROS, A.N.; MADRUGA, M.S. et al. Rendimento de vísceras para "buchada" em caprinos Saanen alimentados com diferentes níveis de volumoso e concentrado. In: SIMPÓSIO INTERNACIONAL SOBRE CAPRINOS E OVINOS DE CORTE, 2., 2003, João Pessoa. Anais... João Pessoa: EMEPA, 2003. (CD-ROM).

COSTA, R.G.; SANTOS, N.M.; MEDEIROS, A.N. et al. Microbiological evaluation of precooked goat "buchada". Brazilian Journal of Microbiology, v.37, p.362-367, 2006.

COSTA, R.G.; VALLEJO, M.E.C.; BERMEJO, J.V.D. et al. Influência do sexo do animal e dos sistema de produção nas características de carcaça de caprinos da raça Blanca Serrana Andaluza. Revista Brasileira de Zootecnia, v.39, n.2, p.382-386, 2010 .

CUNHA, E.; BUENO, M.S.; RODRIGUES, C.F.C. et al. Desempenho e características de carcaças de cabritos Saanen e mestiços Boer. In: REUNIÃO ANUAL DA SOCIEDADE BRASILEIRA DE ZOoteCniA, 40., 2000, Viçosa, MG. Anais... Viçosa, MG: Sociedade Brasileira de Zootecnia, 2000. (CD-ROM).

ERMIAS, E.; YAMI, A.; REGE, J.E.O. Fat deposition in tropical sheep as adaptive attribute to periodic feed flutuaction. Journal of Animal Breeding and Genetics, v.119, p.235-246, 2002.

GARCIA, C.A.; ONTEIRO, A.L.G.; COSTA, C. et al. Medidas objetivas e composição tecidual da carcaça de cordeiros alimentados com diferentes níveis de energia em creep feeding. Revista Brasileira de Zootecnia, v.32, n.6, p.1380-1390, 2003.

GRANDE, P.A.; ALCADE, C.R.; LIMA, L.S. et al. Características quantitativas da carcaça e qualitativas do músculo Longissimus dorsi de cabritos $3 / 4$ Boer + $1 / 4$ Saanen confinados recebendo rações contendo grãos de oleaginosas. Revista Brasileira de Zootecnia, v.38, n.6, p.1104-1113, 2009.

GONZAGA NETO, S.; SILVA SOBRINHO, A.G. et al. Características quantitativas da carcaça de cordeiros deslanados Morada Nova em função da relação volumoso: concentrado na dieta. Revista Brasileira de Zootecnia, v.35, n.4, p.1487-1495, 2006.

HASHIMOTO, J.H.; ALCADE, C.R.; SILVA, K.T. et al. Características de carcaça e da carne de caprinos Boer x Saanem confinados recebendo rações com casca do grão de soja em substituição ao milho. Revista Brasileira de Zootecnia, v.36, n.1, p.165-173, 2007.

LISBOA, A.C.C.; FURTADO, D.A.; MEDEIROS, A.N. et al. Quantitative characteristics of the carcasses of Moxotó and Canindé goats fed diets with two different energy levels. Revista Brasileira de Zootecnia, v.39, n.7, p.1565-1570, 2010.

RIBEIRO, M.N.; GOMES FILHO, M.A.; BERMEJO, J.V.D. et al. Conservação de raças caprinas nativas do Brasil: Histórico, situação atual e perspectivas. Recife: UFRPE, Imprensa Universitária, 2004. 62p.

SILVA SOBRINHO, A.G.; GONZAGA NETO, S. Produção de carne caprina e cortes da carcaça. Jaboticabal: FCAV, 2001. 17p.

SIQUEIRA, E.R.; AMARANTE, A.F.T.; FERNANDES, S. Estudo comparativo da recria de cordeiros em confinamento e pastagem. Revista Veterinária e Zootecnia, v.5, n.4, p.17-28, 1993.

SOUSA, W.H.; BRITO, E.A.; MEDEIROS, A.N. et al. Características morfométricas e de carcaça de cabritos e cordeiros terminados em confinamento. Revista Brasileira de Zootecnia, v.38, n.7, p.1340-1346, 2009. 
TONETTO, C.J.; PIRES, C.C.; MUlLER, L. Rendimentos de cortes da carcaça, características da carne e componentes do peso vivo em cordeiros terminados em três sistemas de alimentação. Revista Brasileira de Zootecnia, v.33, n.1, p.234-241, 2004.

MATTOS, C.W.; CARVALHO, F.F.R.; DUTRA JÚNIOR, W.M. et al. Características de carcaça e dos componentes não-carcaça de cabritos Moxotó e Canindé submetidos a dois níveis de alimentação. Revista Brasileira de Zootecnia, v.35, n.5, p.2125-2134, 2006.

MEDEIROS, G.R.; CARVALHO, F.F.R.; BATISTA, A.M.V. et al. Efeitos dos níveis de concentrado sobre características de carcaça de ovinos Morada Nova em confinamento. Revista Brasileira de Zootecnia, v.38, n.4, p.718-727, 2009.

McClELLAND, T.H.; BONAITI, B.; TAYLOR, St. C.S. Breed differences in body composition of equaly mature sheep. Animal Production, v.23, p.125-129, 1976.

MORON-FUENMAYOR, O.E.; CLAVERO, T. The effect of feeding system on carcass characteristics, non-carcass components and retail cut percentages of lambs. Small Ruminant Research, v.34, p.57-64, 1999.
NATIONAL RESEARCH COUNCIL - NRC. Nutrient requirement of domestics animals: nutrient requirement of goats. Washington, D.C., 1981. 91p.

OSÓRIO, J.C.S.; OSÓRIO, M.T.M.; OLIVEIRA, N.M. et al. Qualidade, morfologia e avaliação de carcaças. Pelotas: Universidade Federal de Pelotas, 2002. 194p.

SANTOS FILHO, J.M. Efeito do peso vivo ao abate sobre algumas características quantitativas e qualitativas das carcaças de caprinos SRD no Estado do Ceará. 1997. $78 \mathrm{f}$. Dissertação (Mestrado em Tecnologia de Alimentos) Universidade Federal do Ceará, Fortaleza.

UNIVERSIDADE FEDERAL DE VIÇOSA - UFV. Sistema de análises estatísticas e genéticas - SAEG. Versão 9.1. Viçosa, MG, 2007. 142p.

ZAPATA, J.F.F.; SEABRA, L.M.A.; NOGUEIRA, C.M. et al. Características de carcaça de pequenos ruminantes do Nordeste do Brasil. Ciência Animal, v.11, n.2, p.79-86, 2001.

YÁÑEZ, E.A.; RESENDE, K.T.; FERREIRA, A.C.D. et al. Restrição alimentar em caprinos: rendimento, cortes comerciais e composição da carcaça. Revista Brasileira de Zootecnia, v.35, n.5, p.2093-2100, 2006. 